\section{NU UNA Kastamonu Eğitim Dergisi Kastamonu Education Journal}

Eylül 2019 Cilt:27 Sayı:5

kefdergi.kastamonu.edu.tr
Başvuru Tarihi/Received: 15.10.2018

Kabul Tarihi/Accepted: 28.12.2018

DOI: $10.24106 /$ kefdergi.3394

Aid Policies Regarding Poor Students With Low Socioeconomic Levels at Schools: Reconsidering Social Justice ${ }^{1}$

\title{
Sosyoekonomik Düzeyi Düşük Yoksul Öğrencilere Yönelik Okullarda İzlenen Yardım Politikaları: Sosyal Adaleti Yeniden Düşünmek
}

\section{Öz}

\author{
Gülay ASLAN²
}

Sosyoekonomik düzeyi düşük yoksul öğrencilere yönelik okullarda izlenen yardım politikalarını değerlendirmeyi amaçlayan bu araştırma, betimsel niteliktedir. Nitel araştırma deseninin kullanıldığı araştırmada, amaçı örnekleme tekniği tercih edilmiştir. Çalışma grubu, 2016-2017 öğretim yılında Tokat ilinde farklı kademlerde görev yapan 55 okul yöneticisi ve 19 öğretmenden oluşmuştur. Araştırmada veriler yarı-yapılandırılmış açık-uçlu sorular yoluyla elde edilmiştir. Yarı yapılandırıımış formda, okullarda yapılan yardım türleri, ne sıklıkta yapıldığı, yardımlara kaynağın nasıl bulunduğu ve bu konuda neler yapılması gerektiğine ilişkin sorulara yer verilmiştir. Veriler, içerik analizi ile çözümlenmiştir. Veri toplama, işleme ve analiz süreçlerinde geçerlik ve güvenirliği artırıcı önlemler alınmıştr. Sonuç olarak, okullarda, sosyo ekonomik düzeyi düşük yoksul öğrencilere yönelik olarak izlenen sistematik ortak politikaların olmadığı, politikaların okul aile birliklerinin bütçelerine ve okulun çeşitli yollarla yarattğı bütçe dışı özel gelir kaynaklarına bağı kaldığı tespit edilmiştir. Okulların çabaları anlamlı olmakla birlikte, makro düzeyde düzenleyici ve bütünsel politikalara gereksinim olduğu görülmektedir. Okullara bütçe ayrılırken, başta sosyoekonomik düzeyi düşük çocukların bulunduğu dezavantajı okullar olmak üzere, okullar arası adaletsizlikleri giderici çeşitli ölçütlerin geliştirilmesi ve okullara bütçelerin bu ölçütlere göre tahsis edilmesi gerekmektedir.

\section{Anahtar Kelimeler: yardım politikaları,yoksul öğrenciler,sosyal adalet, eğitim hakkı, Türkiye.}

\section{Abstract}

The purpose of this descriptive study was to evaluate the aid policies regarding the poor students with low socioeconomic levels implemented at schools. In this qualitative study, purposive sampling technique was used. The participants involved 55 school administrators and 19 teachers working at different school stages in Tokat during 2016-2017 academic year. The data of the study were collected semi-structured open-ended questions. The semi-structured form involved questions regarding the types of aids carried out at schools, their frequency, the funding of aids, and the things to be done about them. The data were analyzed using content analysis technique. The necessary measures were taken to increase validity and reliability during data collection and analysis. As a result, it was found that the schools lacked systematic common policies regarding poor students with low socioeconomic levels and the policies mostly depended on parent-teacher associations' budgets and private income created by schools in various ways. Although the efforts of schools are significant, it can be seen that regulatory and holistic policies are required at a macro level. When the schools are allocated budgets, some criteria should be set to eliminate the injustice among schools; especially those involving poor students with low socioeconomic levels, and the budgets should be allocated based on these criteria.

Keywords: aid politics, poor students, social justice, education right, Turkey

1. This article was presented as abstracts from 18 April to 22 April 2018, at the 25th International Congress of Educational Sciences in Antalya.

2. Tokat Gaziosmanpaşa University, Faculty of Education,Tokat, Turkey; https://orcid.org/0000-0002-4067-0223

Atff / Citation: Aslan, G. (2019). Aid policies regarding poor students with low socioeconomic levels at schools: reconsidering social justice. Kastamonu Education Journal, 27(5), 2203-2220. doi:10.24106/kefdergi.3394 


\section{Extended Abstract}

Introduction: Countries, whether developed or developing, should allocate some of its resources to education. There is not a previously determined sufficient level for this allocation. In addition that education is seen as a function of the modern state, it is brought to the agenda as a public service. One of the primary concerns of education is who and how will bear the cost of education. In liberal economy, answers to this question has been different in the historical process. Especially, during the periods when the capitalist economy had high profit ratios and thus permitted the presence of the social state, it was seen that the resources allocated to education increased. However, during the times when the system was in crisis and thus the social state was on the shelf, the resources gradually decreased. The issue of resource distribution in education is not a problem of demand and supply gap but a problem of dissensus between service preferences of the groups dominating economy and social demands. This is because the decision for the collection and distribution of the resources needed for the public services to run is a serious political issue. The answer differs according to from which direction the problem is viewed.

Today, we are passing through a period where the inequalities created by the resource allocation in education is becoming even greater while the expectations are the opposite. Differences in the facilities and resources between the schools, and degradation in the income distribution could affect the quality of the educational services. Inequalities and injustice created by the resource distribution at macro level are tried to be eliminated by policies at micro (school) level. Fund raising policies based on the parents/surroundings of schools which are disaggregated/divided socio-spatially deepen the inequalities even more.

The purpose of the study is to evaluate/assess the policies at schools for the children coming from low-economic backgrounds. The study aims, in general, to discuss in various dimensions the repercussion of the socio-economic states of families on education, and focuses in practice on the policies carried out in schools at micro level to decrease this effect. Thus, it is a descriptive study.

Method: In this study where qualitative research design was used, purposeful sampling technique was preferred. This is also called judgment sampling. In the determination of school administrators, variables such as title, seniority, gender, age, working in different levels and different provinces were taken into consideration. According to that, the study group consisted of 55 school administrator and 19 teacher working at different levels in Tokat province in 2016-2017 school year. Data was obtained through semi-structured open-ended questions. During the development of the data collection tool, literature was reviewed, and opinions and suggestions of the school administrators were obtained. Draft form was presented to expert view and suggestion to provide content validity of the semi-structured form.

Data obtained in the study was analyzed by content analysis technique. In data analysis, first the answers the administrators gave to the questions were transferred to digital medium. Texts were classified and organized according to the topic titles and answers given to the guide questions related to the topic titles. Each question was accepted as a theme, and sub-themes were obtained based on the answers. Frequencies and percentages were given to the sub-themes and these were digitized.

Results: The results obtained according to the purpose of the study are presented with direct quotations from the administrators' views when necessary. Some of the results of the study could be summarized as follows. There are no systematic common policies that are followed by schools for students with low socioeconomic status. The policies the schools follow are dependent on the incomes created by the school in various ways to the budgets of the school family units rather than the budget of the school. Elementary and secondary school administrators from the surveyed school administrators stated that schools tend towards the compulsory school requirements rather than the support activities for the socio-economic level students.

Conclusion: It seems unlikely that schools will be able to effectively monitor the policies of schools with low socio-economic level. With the efforts made by schools, there is a need for regulatory and holistic politics at the macro level. Existing policies have been seen to deepen rather than eliminate or reduce existing inequalities between students and schools. While administrators are allocating budgets to schools, they have expressed the need to develop various measures to eliminate injustice among schools, particularly schools, which have the disadvantage of having children with low socioeconomic status, and that schools should be allocated budgets based on these criteria. 


\section{Introduction}

Education is a fundamental human right, and the provision of this right is the main responsibility of the State. The education process has a potential to develop and liberate people mentally and socially. It is a universally accepted principle that the State is to provide all citizens education without discrimination due to social class, gender, language, belief, ethnic and minority group differences. For this reason, education is seen as one of the most basic public services (Gök, 2004, p. 94). With reference to this principle, the right of education is assured both by national and international legislation. In Article 42 of the Turkish Constitution, the right of education has been stated as "No one shall be deprived of the right of education. Primary education is compulsory for all citizens of both sexes and is free of charge in state schools." This right has been regulated by international treaties in international legislation. The right of education has been assured in many treaties such as United Nations Universal Declaration of Human Rights (1948; Article 26), United Nations Convention on the Rights of the Child (1959; Article 51), International Covenant on Economic, Social and Cultural Rights (1966, Articles 13 and 14), Additional Protocol to the European Convention on Human Rights (1952; Article 2), Charter of Fundamental Rights of the European Union (2000; Articles 14 and 26), and European Social Charter (Revised) (2007; Articles 13 and 15) and defined as an inseparable part of human dignity (Aslan, 2016, pp. 1-2). Turkey signed all of these conventions. The authorization of international conventions has been explained in Article 90 of the 1982 Constitution as "...International agreements duly put into effect have the force of law. No appeal to the Constitutional Court shall be made with regard to these agreements, on the grounds that they are unconstitutional. In the case of a conflict between international agreements, duly put into effect, concerning fundamental rights and freedoms and the laws due to differences in provisions on the same matter, the provisions of international agreements shall prevail."

Historically, the perception of education as a fundamental human right and being seen as a part of human dignity has originated largely from its economic and political functions, rather than the mental and social development and liberation of the individual by education. For this reason, two important developments can be mentioned, leading to the financing, massification and institutionalization of education with public resources. The first one is French Revolution. The emergence of nation states, expectation of the national consciousness building function from the education, and the emphasis on freedom, equality and fraternity after the French Revolution led both to widespread education at institutional level and to financing through social resources (Ercan, 1998, p. 59). The second one is the Industrial Revolution. With the revolution, patterns of socialization have changed, education has become massive, and production activities have begun to pass from family to factory. This leads to the need to present educational services through social resources (Bowles, 1977). Providing education free of charge or in other words with social resources has not been started in any country at once and in total, but has been put into practice with serious differences in terms of education levels (YIImaz, 2013, p. 48). For example, providing education by the state and viewing it as a public service came to the fore after the 1839 Imperial Edict of Reorganization was issued for the first time during Ottoman Period. In Statute on General Education of 1869, it was declared that primary education would be provided to all citizens compulsorily and free of charge. This development, which is historically very important, has never been fully realized (Gök, 2004, p. 95).

Organization of education by the state and financing it through public resources have brought up debates regarding equality (Özsoy, 2002, p. 35). According to Tan (1987), the concept of equality in education has evolved to equalize outputs (diploma, certificate, income, status, etc.) from equating educational inputs (number and quality of teachers, teaching and learning environment, course tools and equipment, programs, financial resources etc.) in the historical process. Even if this policy could achieve success in equally benefiting from the right of education, equalization of inputs was not enough to equalize outputs of education. Educational inequalities have not been able to be eliminated in many parts of the world, especially in developing countries (Organisation for Economic Co-operation and Development [OECD], 2007; United Nations [UN], 2010; World Bank [WB], 2013). Nevertheless, studies on effective school since the 1960s have shown that it is important to equalize the input / school-related factors in the academic achievement of students in developing countries. This is explained by the limited availability of educational opportunities and the inevitability of inequalities among schools in developing countries (BalcI, 2014, p. 20). Therefore, equalizing and improving the environments and facilities of schools in developing countries is in favor of poor students, especially those with a low socioeconomic level. As the inequalities between schools increase, the students with the lowest socioeconomic level are the ones who suffer the most.

On the other hand, even in equally educated individuals with equal educational opportunities, it has been observed that the benefits of education / benefit from education may also be differentiated based on such factors as socioeconomic level of the family, social class roots, gender roles, religion, sect, ethnicity, etc.. (Tan, 1987). For this reason, it has been generally accepted that the disadvantaged individuals should be treated differently in order to ensure a genuine equality between individuals (Aslan, 2015; Eğitim Reform Girişimi [ERG], 2009). Thus, real equality in education means 
that all variables that prevent students from equally benefiting from education except for individual differences such as intelligence and talent should be controlled by the State. However, not to mention equalizing educational output, equality even on inputs have not been achieved in Turkey. The environment and facilities of schools are at a level that will differentiate educational outcomes. For example, according to the 2003 PISA results, mathematical literacy in Turkey ranks first among OECD countries in terms of inequality between schools, and according to 2006 results, science literacy ranks $11^{\text {th }}$ in terms of inequality between schools (Dinçer \& Kolaşin, 2009). Over the years, inequalities between schools have not decreased. According to PISA 2012 results, 61\% of the variance in students' math scores have been found to arise from differences among schools in Turkey. This rate is $37 \%$ for the average of OECD countries (Anıl, Özer Özkan, \& Demir, 2012, p. 88). In addition, when schools with low academic achievement are examined, it is seen that they are the schools in which students with low socioeconomic level concentrate (ERG, 2015, 2016). The data show that inequalities among schools in Turkey are deep and poor students intensify at schools with low achievement.

Still, the provision of education by the state free of charge has forced all countries to allocate some of their resources to education although it shows differences in developed and developing countries. There is not a predetermined level of resources for a country to allocate education. However, who will bear the cost of education and how it will be met remains one of the major problem areas. In the liberal economy, the answers given to this question differ in the historical process. It has been seen that the resources allocated for education have increased, especially during periods when the capitalist economy has had high profits and therefore allowed the social state to live. However, resources have gradually decreased in the periods when the system has entered the crisis, the profit rates have fallen and therefore the social state has been by-passed (Apple, 2004; pp. 98-111; Boratav, 1997; Ercan, 1997, 1998; Gök, 2004; Önder, 2002; Stewart, 1995; Kurul, 2012; Ünal, 2002; Yılmaz, 2013, pp. 47-56). For this reason, the problem of resource allocation in education is not a problem of supply and demand dispute but it can be considered as a problem of disagreement between the preferences of the dominant economists for service and the social demands since the way in which the resources that enable public services to be collected through taxation and how to distribute them is a highly political decision in a system.

With the neo-liberal policies implemented especially after 1980 in Turkey, emphasis on the necessity to downsize the state has affected the provision of all services including education. Together with these policies, the promotion of private schools, rather than improving the quality of state schools, has been viewed as a policy (Aslan, 2015). It is possible to notice it by the indicators related to the incentives given to private schools and the increase in private school numbers. When the Ministry of National Education (MONE) and Higher Education Council (HEC) data regarding the years between 2000-2001 and 2016-2017 academic years are examined, it can be seen that the number of students at state schools was multiplied by 4.6 at preschool education, 0.9 at primary education, 1.8 at secondary education, 5.7 at non-formal education, and 2.9 at higher education. In the same period, the number of students at private schools was multiplied by 12.4, 2.7, 8.9, 1.2, and 10.7, respectively (MEB, 2017a; YÖK, 2017). Incentives provided for private schools by the state have been effective in this increase. For example, a total of 340 thousands students are declared to benefit from the incentives during the 2017-2018 academic year. The ministry aims at increasing the number of students at private schools to 15 percent until 2013. The authorities of ministry expressed that they paid 2 million 859 thousand 950 liras to private schools within the scope of incentives until 2017-2018 academic year (MEB, 2017b).

The second significant effect of neo-liberal policies is the decline in public sources allocated to education. While the number of students in state schools has increased at all levels, the resources devoted to educational investments from the Gross Domestic Product (GDP) and the Central Budget have decreased. In 2000, the share of MONE investment budget in total education budget decreased from $19.9 \%$ to $8.9 \%$ in 2015. In addition, the share of the MONE budget in the consortium investment budget has declined from $28.4 \%$ in 2000 to $13.6 \%$ in 2015, and the share in GDP from $0.40 \%$ in 2000 to $0.28 \%$ in 2015 (MEB, 2017). The increase in the number of students at all levels in the relevant period and the marked decrease in the investment budget may mean that the state is gradually withdrawing from education in general and education investments in particular and has left schools to their fate. The lack of resources allocated from the central budget to especially primary and secondary schools and the inadequacy of this resource in secondary education institutions have forced schools to seek extra budgetary resources and have left them at the mercy of parents and / or charity.

Research shows that education, especially primary education, has become a serious burden for families. In studies conducted by Kavak, Ekinci, and Gökçe (1997), Kesin and Demirci (2003), and Yolcu (2007), it was found that from 27 to 60 different extra budgetary resources were created in primary schools in Turkey. At one hand, the expectations for more qualified school education by society, on the other hand, budget constraints depending on the neo-liberal policies have led school administrators to find new extra budgetary resources. In fact, when the years in which the re- 
searches are conducted are examined, it is observed that school-based money rises gradually with different names in the schools. It has also been found that the activities carried out by schools in order to increase the quality of education are different depending on the extra budgetary resources they have acquired. These studies show that the greatest burden is on the parents in the created extra budgetary sources and that the principle of "those benefiting from the service pay for it" has become established.

On the other hand, the environment and facilities of schools and the socioeconomic circles that students come from are different from each other. The source created by parents / nongovernmental organizations or benefactors seems to deepen inequalities in education and to strengthen dissociation among schools (Aslan, 2016, p. 3; Kiraz, 2014; Ünal et al., 2010). However, according to Âdem (1993, pp. 183-184), it is required to search for and provide adequate monetary resources, distribute it equally among the various sub-sectors, and utilize the available resources effectively so that the training activities can be carried out at the desired level. Otherwise, it is not possible for the education system to meet the demand for qualified and high quality labor and the demand of the education of the nation. A similar concern has been expressed by Karakütük (2012, p. 345). Karakütük stated that the most important problem faced by educational organizations in terms of budget management is budget deficiency. This would mean that schools or universities could not fulfill their essential functions and that quality in education would fall.

Budgetary practices of MONE regarding the schools cannot eliminate the disadvantages arising from family structure in Turkey. Increasingly, families spend more on education, and these inequalities are becoming more and more intense rather than eliminating disadvantages and inequalities originating from families. Differences in the environments and possibilities of schools and increasingly distorted income distribution can affect the quality of educational services. According to the distribution of income in Turkey based on 20\% sequential slices of 2012 household consumption expenditures, the share of the first $20 \%$, which is the lowest income group in total education expenditures, was $2.3 \%$ while the share of the fifth highest $20 \%$ was $66.8 \%$ (Türkiye İstatistik Kurumu [TÜiK], 2013). This skewness in educational expenditures is a determining factor in the development of educational inequalities such as children's access to education, school success, school attendance and quality of education. Budget policies followed for the schools in Turkey is far from being correct this distortion.

The inequalities and injustices created by macro-level resource distribution are being tried to be solved by policies at the micro (school) level. Socially and spatially divided schools' policies of creating resources based on benefactors / parents deepen the inequalities between schools. In addition, leaving the education to the mercy of benefactors has eliminated the idea of a better future gained by education for the poor class because it is only through qualified education that social mobilization can be achieved in terms of poor class. Therefore, the provision of educational equality is one of the important problems of Turkey. In order to ensure equality and social justice in education, it is necessary to abolish environment, opportunity, and quality differences between schools in terms of education access and achievement, and secondly, to implement policies that minimize the effects of some personal characteristics such as children's socioeconomic level, social class roots, gender roles, religion, and ethnicity on educational settings. Such differences may bear the risk of recreating inequalities in income and quality of life among these groups through education. However, education is the most important tool of social mobilization. Education should be used at the highest level of potential to reduce social inequalities. It is also a requirement for a democratic and pluralistic society order. The elimination of equal dismissal in education will be possible by strengthening socioeconomic and academic infrastructures (Aslan, 2015; ERG, 2009).

Although there are reports and studies on inequality in education and financial problems of schools in literature (Aslan, 2015, 2017; ERG, 2009, 2015, 2016; Ercan, 1998; Gök, 2013; OECD, 2007; Tan, 1987; Tourch, 2005; Ünal et al., 2010; WB, 2013; Yolcu, 2007), no study on what kind of practices are undertaken for poor students with low socioeconomic level in Turkey has not been found. This research is expected to fill this gap. According to Hoy and Miskel (2010, pp. 39-81), the technical foundation of school is learning and teaching and it requires the success of all students and the monitoring of student development. However, schools do not have enough time for educational problems since they spend their time dealing with budget problems that are out of the function of education and instruction. Addressing the problems that schools face can lead to educational policy makers to solve these problems at the macro level. In the research, it was aimed to evaluate the aid policies observed in schools for poor students with low socioeconomic level. Within the scope of this objective, the following questions were asked:

- What kind of aid is provided for poor students with low socioeconomic level at schools?

- What is the frequency of the aids?

- What should be done for poor students with low socioeconomic level according to school administrators and teachers? 


\section{Method}

This study, which aims to discuss the reflections of the socioeconomic status of the families in general on various dimensions, has focused on the policies observed at the micro level in schools to reduce this effect in practice; for this reason, the research is descriptive.

\section{Participants}

In this qualitative research, purposive sampling technique was used. This is also called judgement sampling. In this type of sampling, the researcher uses his/her own judgments about who to choose and includes the most appropriate ones for the purpose of the research. The advantage of this approach is that the researcher uses his/her previous knowledge and skills in the selection of the subjects (Balcı, 2004, s. 90). Due to the possibility of differences in participants' views in terms of some variables such as the personal characteristics and/or the environment of the schools where they work, care was taken to ensure that the participants who work in settlements with different experiences were involved in the sample as much as possible. Therefore, variables such as title, experience, gender, age, occupation at different levels and different districts were taken into account when school administrators and teachers were selected. Accordingly, 55 school administrators (school principals and assistant principals) and 19 teachers who worked at different levels in the province of Tokat during the 2016-2017 academic year have been involved in the study. It was preferred that the number of administrators was higher than the number of teachers among the participants because the school administrators are the decision-making authority for the aid policies implemented in schools. They are the persons who govern the practices and make the final decision. On the other hand, in determining the students and/or parents to be aided in schools, various commissions are formed and teachers are involved in these commissions. For this reason, the study involved the teachers taking part in these commissions. Demographics are presented in Table 1.

Table 1. Demographics

\begin{tabular}{lll}
\hline Personal characteristics & & f \\
\hline Gender & Female & 16 \\
Title & Male & 58 \\
& Principal & 55 \\
Mean age & Teacher & 19 \\
Mean experience of teaching & Year & 38 \\
Mean experience of administering & Year & 8 \\
& Year & 7 \\
Education level & Preschool & 9 \\
& Primary & 22 \\
& Middle & 19 \\
Socio-economic level of the school & Secondary & 24 \\
& Low & 35 \\
\hline
\end{tabular}

As can be seen in Table 1, 16 participants were female while 58 were male. Moreover, 55 were principal and 19 were teachers. The mean age of participants was 38. The mean of their teaching experience was 8 years while the mean of their administration experience was 7 years. Of the participants, 9 were working at preschool, 22 in primary school, 19 in middle school, and 24 in secondary school. 35 of the participants was working at schools involving students with low, 27 was working at schools involving students with middle and 12 was working at schools involving students with high socio-economic backgrounds. Some additional demographics of participants were presented in Appendix-1.

\section{Data Collection and Analysis}

The data of the study were gathered using semi-structured open-ended questions. The relevant literature was reviewed and the views and suggestions of school administrators and teachers were taken during the development of data collection tool. The opinions of the faculty members with the expertise and experience in the subject were taken regarding the prepared form and the final version of the items was obtained based on their feedback. The experts were asked to evaluate the draft of the tool. Thus, the content validity of the semi-structured form was tried to be ensured. At the end of this process in the direction of the proposals, 13 items, nine personal and four regarding the aid policies carried out at schools, were obtained. 
The interview form was delivered to the schools by the researcher in May. Before the form was implemented in schools, an appointment was made from the school administrators and the purpose of the study was explained. The responses of participants were taken in written since some of the pre-interviewed administrators expressed that they did not have enough time for the interview and the inclusion of more managers was desired. This situation was similar in teachers. Teachers stated that they were mostly in lessons during their time in the school and that they would report their opinions in written because they left the school at the end of the course. The teachers were not determined beforehand and they were selected according to the opinions of the managers. During the interviews, the names of the teachers who took part in the school's aid committees were asked and the form was applied to those teachers who accepted to participate in the study. The administrators and teachers were given a one-week period to fill in the forms, after which the forms were collected by the researcher.

The data of the study were analyzed using content analysis technique. Content analysis is performed in cases where research is not very clear in theory or needs a more in-depth analysis (Yıldırım \& Şimşek, 2008). In the analysis of the data, firstly the answers given by the managers and the teachers to the questions have been entered into the computer. Then, the computer files were sent to an expert, and his approval was taken whether the data were transferred to the computer correctly. The texts were classified and arranged according to the topics of the interview and the answers given to the question. Each question was accepted as a theme and sub-themes were derived from the answers given by the administrators and teachers to the questions. Sub-themes were quantified using frequencies. According to $\mathrm{Y}_{1}$ ldırım and Şimşek (2008, pp. 177), there are several basic purposes in the quantification of qualitative data. These are to increase reliability, to reduce bias, and to allow comparison between the resulting themes and categories. In the last step of the analysis, the themes and sub-themes were presented to experts in the educational sciences and qualitative research, and the inter-coder reliability was obtained. In this process, reliability = [number of agreements/ (number of agreements+ disagreements)] X 100 formula (Miles \& Huberman, 1994) was used and inter-coder reliability was found as $94.1 \%$. An agreement percent of $70 \%$ or higher shows that reliability was ensured according to Miles and Huberman (1994).

Participants were coded as P1, P2, ... P74. Other descriptive information was presented without coding. Accordingly, in the direct quotations from participants, codes, gender, job (branch if he/she is a teacher), and the school level the participants works were presented respectively (P2/ male / principal / primary school).

\section{Measures Regarding the Validity and Reliability of the Study}

Validity in qualitative research is related to the accuracy of scientific findings and reliability is related to the reproducibility of scientific findings (Yıldııım \& Şimşek, 2008). In this respect, some measures have been taken to increase the validity and reliability of the study. These are: (i) A comprehensive conceptual framework has been formed based on the relevant literature to increase the internal validity (credibility) of the research while developing the semi-structured form. At this stage, pre-interviews were made with the school administrators and teachers and these views were used in the preparation of the form. On the other hand, permission was obtained from each school for the application. In addition, the purpose of the research was explained in order for the administrators and teachers to express their opinions without any concern or fear. Thus, it was tried to ensure that the data collected during the interview process reflected the real situation. (ii) In order to increase the external validity (transferability) of the research, the research process and the actions taken in this process were explained in detail. In this context, the model of the study, the participants, the data collection tool, the data collection process, the analysis and interpretation of the data were described in detail. In addition, in order to increase the external validity in the study, maximum diversity was tried to be provided among the participants. Particular care was taken to include schools from different socio-economic backgrounds and different levels of schools in the study. (iii) In order to increase the internal reliability (consistency) of the research, all of the findings were given directly without interpretation and were supported by direct quotations from the views of the participants. In order to increase the reliability of the research, expert opinion was used at every stage of the research (preparation of semi-structured form, checking data transferred to computer environment, creating theme and sub-themes). In addition, a faculty member studying in the field of educational sciences and experienced in qualitative research methods made coding independent of the researcher and the codes were compared calculating the agreement percentage. (iv) A detailed description was made to increase the external reliability (replicability) of the study. The findings were written in detail and the participant codes were arranged and presented in a way that allowed the control of the consistency of the data in the findings section. 


\section{Findings}

Findings obtained within the scope of the research purpose are presented by using direct quotations from the views of the administrators and teachers.

\section{Aids Carried Out at Schools}

The first aim of the study was to determine what kind of aids is provided to poor students with low socioeconomic status at schools. The responses of the participants to this question are presented in Table 2.

As can be seen in Table 2, the poor students were provided with clothing and footwear aids $(f=46)$, stationary aids $(f=38)$, financial aids $(f=24)$, lunch aid $(f=6)$, food aids for parents $(f=6)$, exempting students from school fee $(f=6)$, free participation in social activities organized by the school $(f=4)$, providing student scholarships $(f=3)$, satisfying travel expenses for children's school access $(f=2)$, and academic support $(f=1)$.

\section{Table 2. Aids provided to students with low socioeconomic status at schools}

\begin{tabular}{|c|c|c|}
\hline Sub-Themes & $f$ & Participant Codes \\
\hline Clothing and footwear aids & 46 & $\begin{array}{l}\text { P1, P2, P6, P7, P8, P11, P14, P15, P16, P17, P18, P20, P22, P23, P24, P25, } \\
P 26, P 29, P 30, P 31, P 33, P 34, P 35, P 36, P 37, P 39, P 40, P 41, P 43, P 44, P 45 \\
P 46, P 47, P 48, P 50, P 54, P 55, P 60, P 61, P 62, P 64, P 66, P 67, P 68, P 69, P 72\end{array}$ \\
\hline Stationary aids & 38 & $\begin{array}{l}P 1, P 2, P 3, P 6, P 7, P 11, P 14, P 15, P 16, P 18, P 20, P 21, P 23, P 24, P 25, P 26, \\
P 29, P 30, P 31, P 33, P 36, P 37, P 39, P 41, P 43, P 44, P 47, P 48, P 49, P 54, P 55, \\
P 61, P 62, P 64, P 66, P 68, P 71, P 74\end{array}$ \\
\hline Financial aids & 24 & $\begin{array}{l}P 1, P 2, P 3, P 4, P 11, P 18, P 19, P 21, P 23, P 24, P 25, P 26, P 27, P 28, P 31, P 37, \\
P 39, P 44, P 45, P 54, P 56, P 61, P 69, P 73\end{array}$ \\
\hline Lunch aid & 6 & P5, P12, P26, P30, P34, P37 \\
\hline Food aids for parents & 6 & P7, P25, P32, P35, P40, P46 \\
\hline $\begin{array}{l}\text { Exempting students from school } \\
\text { fee }\end{array}$ & 6 & P41, P43, P49, P52, P64, P65 \\
\hline $\begin{array}{l}\text { Free participation in social activ- } \\
\text { ities }\end{array}$ & 4 & P38, P50, P66, P73 \\
\hline Scholarship & 3 & P18, P53, P67 \\
\hline Travel expenses & 2 & P5, P34 \\
\hline Academic support & 1 & P49 \\
\hline Total & 135 & \\
\hline
\end{tabular}

Teachers and administrators' statements show that aids differ among schools. Based on the regulations in Turkey, poor students are determined by establishing a commission at the beginning of each academic year. However, the amount of aid to be provided, the types of these aids, and how often it will be made depends entirely on the facilities of the school. Therefore, the types of aids, how often and how they are to be done differ from school to school. When the aids are examined, it appears that they concentrate on the basic school needs of the students. Clothing aids for students are mostly school uniforms, winter jackets or shoes. Indeed, some of the administrators stated that:

In the first month of school opening, stationery and uniforms (clothes) are usually provided, and in the winter season, clothes are usually provided. In addition, a limited number of poor students are paid with Conditional Cash Benefits of the Social Assistance and Solidarity Fund as monthly salary. However, this is a very low amount, and it is only possible to be a school allowance. This amount is not given to all poor students. In addition, philanthropic citizens, public institutions, and associations are providing financial aids irregularly (P2 / male / principal / primary school).

On the other hand, school administrators and teachers talked about practices that could harm children's personality development and cause them to be offended while talking about helping them. For example, two participants expressed the following:

Sometimes unethical occasions occur while providing aids to poor students. For example, students wear old and torn clothes in order to be able to get the aid and parents are persistent, which leaves us in a difficult position. In addition, charitable organizations, charities or philanthropists can use it advertising and display. This can lead to situations that should not be experienced in the educational environment (P5 / female / principal / primary school).

We are dealing with the poor students in our school, doing personal and institutional cash contributions 
such as school form, shoes, stationery materials and school allowances. However, there are drawbacks of this practice on children. Even if we do not feel it, the student knows and understands it. One side of the individuals who grow up with help is missing because this person is grateful for this help. She/he also always feels the frustration of poverty and is encouraged to beg. As long as these supports are not presented as a right by the state and they are not regular, these negativities will always be felt (P24 / male / principal / secondary school).

Moreover, when the aids to students were examined, it was observed that some schools provided food aid for students' parents. However, it appears that such assistance is limited and not systematic. For example, one of the administrators stated:

We determine the level of poverty of poor children, and determine the extent to which they are poor. In this way, we intervene according to the order of priority of our students. If the family of the student needs food, we provide food. If they need clothing, we provide clothing. However, we can do it once or twice a year. Unfortunately, there is no such a chance in the other months of the year. We are not sure whether this serves as a solution for the family. This is what we can as a school because our resources are limited (P25 / male / principal / secondary school).

The aids for the poor students differ according to the school stages as well as the schools. Preschool education in Turkey is outside the scope of compulsory education. Preschool education are offered by different institutions. If this education is provided by the state's independent kindergartens, then even in public schools, the families have to pay the fee determined by the State. An independent kindergarten principal stated:

Every parent who sends a child to our school has to pay a monthly fee that the state has set. However, when they proved that they are poor, they are entitled to free registration for one-tenth of the school quota (P41 / female / principal/ preschool).

Undoubtedly, academic support is at the forefront of the most needed aid for poor students with low socioeconomic levels because it can be seen that parents' education levels are low when the family structure of these children are examined. This means that parents cannot provide academic support for their children at home. Only one of the participants stated that they provided academic support for the poor students at the school:

The students who come from families with low socioeconomic level are monitored by their teachers in terms of adaptation to the school environment and academic achievements and they are tried to be brought to the same level with their peers. Parents are visited in a family setting. Thus, the situation is determined and communication with the student and the family is strengthened. The more sincere and realistic the student is with the teacher, the more successful she/he is. We take care to have activities that enhance the taste of achievement and self-esteem of these students (P49 / female / principal / preschool).

Moreover, administrators working in primary and middle schools stated that the schools in Turkey are not allocated any money from the central budget. They expressed that for this reason, contributions from various sources, especially from the parents, are used to meet the basic expenses of the school instead of supporting poor students. One of the participants stated:

Actually, helping poor students and meeting their needs is legally the duty of the Parent-Teacher Associations. However, the money collected in Parent-Teacher Associations are used for schools' expenses such as the walls of the school, painting, stationery, and so on. That is because primary and middle schools do not have the resources allocated from the central budget. These schools create their own budgets with either aids or donations. Therefore, their budgets are limited. With this budget, both the schools' expenditures and the poor students are being assisted. For that reason, these aids are not at an expected and desired level. Especially in schools where the socioeconomic level of their parents is low, the situation is even worse. These schools are not able to collect enough help / donations from their parents to meet the basic needs of the schools, not to mention helping students (P39 / male / principal / middle school).

\section{The Frequency of Aids}

The frequency of the aids is as important as the aids themselves. For this reason, it was also asked to participants how often the aids are made in their schools. The responses of the participants are presented in Table 3. 
Table 3. The frequency of school-based aids for students with low socioeconomic status

\begin{tabular}{|c|c|c|}
\hline Aid Frequency & $f$ & Aid Type \\
\hline Once or twice a year & 100 & 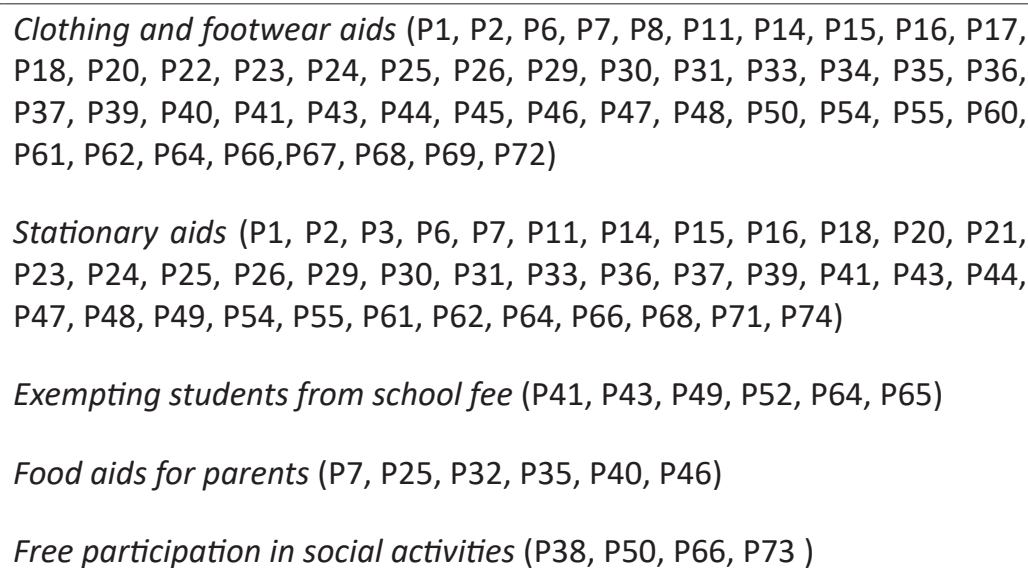 \\
\hline Monthly & 27 & $\begin{array}{l}\text { Financial aids (P1, P2, P3, P4, P11, P18, P19, P21, P23, P24, P25, P26, } \\
\text { P27, P28, P31, P37, P39, P44, P45, P54, P56, P61, P69, P73) } \\
\text { Scholarship (P18, P53, P67) }\end{array}$ \\
\hline Daily & 9 & $\begin{array}{l}\text { Lunch aid (P5, P12, P26, P30, P34, P37) } \\
\text { Travel expenses (P5, P34) } \\
\text { Academic support (P49) }\end{array}$ \\
\hline Total & 136 & \\
\hline
\end{tabular}

When Table 3 is examined, it is seen that a significant part of the aids are made once or twice a year $(f=100)$ and not regular. It is seen that monthly aid is usually monetary aid and that the school is leading poor students to the Social Assistance and Solidarity Fund. It is stated that the monthly cash aids (\$12 per month) given to the students by this Fund are very low, these students cannot meet all their needs and it can be given to a small number of students. It is seen that the daily aid is mostly travelling or lunch meal. School administrators and teachers often stated that it is not possible to solve the problem of poor students with the policies the schools follow because the aid made in schools is arbitrary.

Of course, the aids can help students improve their educational opportunities, but they will never be enough. You cannot solve the people's problems just by doing stationery, clothing aids once a year. These aids need to be regular and systematic. There are serious differences between schools. Aids are provided at some schools once a year, at some twice, and at some not at all. The problem needs to be solved with macro policies (P13 / female / teacher / primary school).

I think that rather than providing poor students with little and unsecured aids, the state should determine poor students and provide them with regular financial assistance during their education (P26 / male / principal / middle school).

Poor children must be aided by the state and it must be systematic. These children must be rescued from the forms of help that are obscure and uncertain (P70 / female / assistant principals / preschool).

\section{The Source of the Aids}

School administrators and teachers were also asked how they provided the source / budget for the help made for poor students in schools, and the data are presented in Table 4. Since primary schools do not have a separate budget allocated from the center, there is no separate budget for poor students. For this reason, since the aids are created through school facilities, environmental facilities, parent support, teacher support, etc., the amount of the aid, the type, and the way in which the school has earned and spent can differ among schools. 
Table 4. The source of aid for poor students with low socioeconomic levels

\begin{tabular}{|c|c|c|}
\hline Sub-theme & f & Participant Codes \\
\hline $\begin{array}{l}\text { In-kind and cash benefits collect- } \\
\text { ed from school staff }\end{array}$ & 29 & $\begin{array}{l}\text { P3, P5, P7, P8, P9, P11, P14, P16, P17, P18, P30, P31, P33, P37, P38, } \\
\text { P39, P40, P43, P44, P46, P48, P49, P53, P54, P55, P56, P57, P60, P69 }\end{array}$ \\
\hline $\begin{array}{l}\text { Public institutions and municipal- } \\
\text { ities }\end{array}$ & 18 & $\begin{array}{l}\text { P2, P6, P14, P15, P16, P26, P32, P38, P43, P47, P51, P55, P57, P58, } \\
\text { P59, P60, P63,P70 }\end{array}$ \\
\hline Philanthropic citizens & 18 & $\begin{array}{l}\text { P1, P2, P8, P13,P15, P18, P25, P28, P30, P31, P40, P43, P44, P45, } \\
\text { P47, P51, P55, P60 }\end{array}$ \\
\hline $\begin{array}{l}\text { Parent-Teacher Association reve- } \\
\text { nues }\end{array}$ & 15 & $\begin{array}{l}\mathrm{P} 1, \mathrm{P} 2, \mathrm{P} 8, \mathrm{P} 10, \mathrm{P} 18, \mathrm{P} 30, \mathrm{P} 39, \mathrm{P} 44, \mathrm{P} 45, \mathrm{P} 54, \mathrm{P} 57, \mathrm{P} 62, \mathrm{P} 66, \mathrm{P} 67, \\
\mathrm{P} 71,\end{array}$ \\
\hline $\begin{array}{l}\text { Associations or non-governmen- } \\
\text { tal organizations }\end{array}$ & 11 & P2, P6, P8, P14, P18, P26, P31, P48, P51, P55, P58 \\
\hline Companies & 10 & P15, P16, P25, P30, P33, P51, P54, P60, P67, P68 \\
\hline $\begin{array}{l}\text { Students (Clothes collected from } \\
\text { students) }\end{array}$ & 5 & P1, P18, P30, P33, P70 \\
\hline $\begin{array}{l}\text { Income from charity sales, school } \\
\text { trips, exhibitions, etc. }\end{array}$ & 5 & $P 22, P 24, P 27, P 51, P 60$ \\
\hline Sister School Partnerships & 3 & P45, P54, P65 \\
\hline Graduates & 1 & P53 \\
\hline Total & 115 & \\
\hline
\end{tabular}

When Table 4 is analyzed, it is seen that aid for poor students is financed by 10 different sources. Some of these resources are not only for poor students, but also for the private expenditure of the schools. These include, for example, income from parent-teacher associations, contribution of parents, income from donations, charity sales, school trips, exhibitions, and/or donations from philanthropic citizens. When Table 3 is examined, it can be seen that the in-kind or cash benefits for poor students are diversified from the money collected from the school staff to the second hand clothes collected from the students. For this reason, there are different practices among schools regarding the sources from which the aids are provided. Some of the teachers and school administrators expressed the following regarding the source of the in-kind and cash aids to poor students:

In our school, we try to deliver the money or supplies that come from various public institutions or individuals to poor students. From time to time, aids made through the Social Assistance and Solidarity Fund are delivered to these families. However, these aids are very limited and insufficient. For this reason, the money that the school staff collect among themselves is also sometimes delivered to these students / families. (P9 / male / assistant principal / middle school).

We established a fund for poor students at our school. This fund provided a flow of resources from the salaries of our teachers at an amount that they determined. We make it possible for students who need this source to get aid (P30 / male / teacher / secondary school).

We try to afford the aid to poor students from the revenues of parent-teacher association, the charity sales and exhibitions organized by the school, the donations made by philanthropic citizens, the help of Conditional Cash Transfers, the stationery, clothes, etc. sent by some companies as well as help from some associations and foundations (P51/male / teacher / secondary school).

\section{Policies that Should be Followed Regarding the Poor Students}

Within the scope of the research, the school administrators and teachers were asked about what should be done about the poor students in the schools and the data are presented in Table 5. The recommendation of school administrators and teachers to poor students is categorized under 10 themes. In the study, it was observed that although the aids to poor students, the frequency of these aids, and the sources differed, the administrators and teachers focused on similar views on the solution of the problem. An important part of the school manager teachers stated that it was not possible to solve this problem at school level and that macro level measures had to be taken. 
Table 5. School administrators and teachers' views on policies to be followed for poor students with low socioeconomic level

\begin{tabular}{|c|c|c|}
\hline Suggestions & f & Participant Codes \\
\hline $\begin{array}{l}\text { Social state should be carried into } \\
\text { effect; the state should meet all } \\
\text { the needs of these students. }\end{array}$ & 30 & $\begin{array}{l}\text { P1, P2, P3, P4, P6, P9, P10, P11, P12, P17, P19, P25, P26, P27, P28, } \\
\text { P31, P39, P40, P43, P45, P48, P52, P55, P61, P62, P63, P66, P68, } \\
\text { P69, P70 }\end{array}$ \\
\hline $\begin{array}{l}\text { More resources from the gener- } \\
\text { al budget should be allocated to } \\
\text { schools receiving students from } \\
\text { low socioeconomic environments. }\end{array}$ & 16 & $\begin{array}{l}\text { P4, P16, P19, P20, P22, P27, P28, P30, P31, P34, P35, P46, P47, P63, } \\
\text { P73, P74 }\end{array}$ \\
\hline $\begin{array}{l}\text { Funding for poor students should } \\
\text { be established at schools. }\end{array}$ & 15 & P4, P20, P22, P27, P47, P54, P67, P72, P73 \\
\hline $\begin{array}{l}\text { The government should provide } \\
\text { employment / employment op- } \\
\text { portunities for the families of poor } \\
\text { students. }\end{array}$ & 6 & P3, P4, P5, P30, P35, P60, \\
\hline $\begin{array}{l}\text { Sister school projects should be } \\
\text { promoted and solidarity among } \\
\text { schools should be increased. }\end{array}$ & 4 & P17, P42, P47, P54 \\
\hline $\begin{array}{l}\text { Non-governmental organizations } \\
\text { should be strengthened and they } \\
\text { should do the help. }\end{array}$ & 2 & P5, P18 \\
\hline $\begin{array}{l}\text { All the needs of these students } \\
\text { must be met by local authorities. }\end{array}$ & 2 & P17, P47 \\
\hline $\begin{array}{l}\text { The support should be asked from } \\
\text { graduates. }\end{array}$ & 2 & P53, P72 \\
\hline $\begin{array}{l}\text { These students should be given the } \\
\text { opportunity to boarding. }\end{array}$ & 1 & P7 \\
\hline $\begin{array}{l}\text { Poor students should be provided } \\
\text { with free breakfast. }\end{array}$ & 1 & P27 \\
\hline Total & 79 & \\
\hline
\end{tabular}

When Table 5 is examined, it can be seen that a significant number of school administrators and teachers have stated that the solution of the problem is to sustain the social state. In fact, this proposal made by the school administrators and teachers is a constitutional requirement in Turkey. According to Article 5 of the Constitution of the Republic of Turkey, Turkey is a social state of law. School administrators and teachers have also pointed out the current inequalities when they say that the social law state has to do what is needed to be done. Some of the participants stated:

Poor students should be brought to the same level as the rich in terms of education. It is obvious that you will not be able to ensure this equality by sending a pair of shoes to schools. The system itself now creates discrimination. It says to the rich 'go to college, I will provide the necessary financial support' and to the poor 'go to go to state school'. Thus, all of the public schools have become the places where poor students are involved. The capitalist system itself produces it. Equality in education cannot be achieved only by offering the same school, the same curriculum, and the same book. Students have to be able to wear in certain standards, to be fed in certain standards, that is, to provide the enough economical support to do them. When it is achieved, a parent does not come and say 'I cannot buy shoes or uniform to my child, and she/ he is too shy to go to school'. Then we will have some degree of equality. A student who cannot get dressed like a friend and get the course material that the teacher asks, either does not come to the school that day or comes to the school but feels overwhelmed. If necessary precautions are not taken, she/he leaves the system. The solution is to ensure the state of law (P14 / male / assistant principal / secondary school). Of course, the aids can help students improve their educational opportunities, but they will never be enough. You cannot ignore the reality just by doing stationery and clothing aids. For a general improvement, it is necessary to take measures to ensure social justice as a state policy (P66 / male / principal / secondary school).

One of the teachers emphasized that aids made in schools should be considered on the basis of rights, not philanthropy while presenting the proposal. According to the teacher, treating the problem of poverty on the grounds of rights is more of a continuous solution, not temporary, in terms of the pedagogical development of children. However, the aids in the current system when, how, and to what extent the aids will be provided are temporary solutions. The teacher said: 
The most important thing to do for the poor is to meet all the needs of these children as a social state. The understanding of the social state expresses an understanding that the issues such as the provision of permanent income for everyone and the benefit of education and health services for everyone are taken in the context of the concepts of rights for individuals and obligations for the state. Yet, philanthropy is a different concept. You donate if you want or you will not if you do not. Both education is a long process, and poverty is not a temporary and day-to-day situation. For this reason, if the social state is fulfilled, no aid is needed (P31, male / teacher / primary school).

However, neo-liberal policies adopted in Turkey and many parts of the world education have abandoned the fields such as education, health and social security to market conditions, and have bound the state's responsibilities in these areas to a regulatory limit rather than a provider of these rights. In fact, the gradual decrease of the resources allocated for the education investments and the incentive to the private sector are the most concrete indicators of this situation. This means that families have to spend more on their children's education. However, in the case of the poor families, there is a need for some children to bring money to the house rather than spending enough money for their education. For this reason, among the proposals of the participants is the elimination of income distribution disorder in the country and the employment opportunities for the poor. Some of the participants expressed:

We should focus on the solution at the macro level, not at the school level. Ultimately, the basic solution is to improve income distribution because a large part of our parents works in day-to-day jobs, so there is no regular income. Most of them benefit from Social Assistance and Solidarity Fund, from the aid known as child money, from fuel aid etc. What needs to be done is to use the resources allocated to the aids for the permanent employment. In a sense, it means 'to teach fishing'. It would be beneficial to extend the scope of vocational courses for adults, to encourage the poor to participate in these courses and to provide employment for them (P60 / female / assistant principal / primary school).

I think that policies that will improve the socioeconomic status of the family should be followed instead of finding the poor students and eliminating it for once. The family should be treated as a whole and should be provided with financial, spiritual, sociocultural, and psychological support, if necessary. If the mother or father is young and able to work, they can be given job opportunities to continue their life according to their talents and abilities. If this is can be done, the poor student may continue his education in the following periods without even needing support. In other words, instead of a one-time financial aid, the family as a whole can be improved, which perhaps reduces the number of students needing aids but increases the quality of the aids indefinitely (P61 / female / assistant principal / secondary school).

On the other hand, when Table 5 is examined, it can be seen that some suggestions were made such as the allocation of budget to the schools that do not have a share from the central budget such as primary and middle schools, the provision of more funds to schools in poor environments, the establishment of funds for schools involving poor students, the dissemination of sister school practices, the strengthening of non-governmental organizations, and supporting poor through local governments.

\section{Discussion, Conclusion, and Recommendations}

Whatever the economic system is, education in every country is a policy question before anything else (Âdem, 1993, $\mathrm{p} 1$ ). Therefore, the policies followed by the countries depending on the economic systems that they adopt determine whether education attains the status of rights. According to Özsoy (2004), education requires public responsibility since it is a fundamental human right. In other words, the government must take the necessary precautions for disadvantaged groups (such as the poor), without any discrimination and offer quality education free of charge to all. If education is not seen as a public responsibility but a property that can be bought with money, this view transforms it into a privilege that can be utilized based on the financial possibilities of people, not a right. Thus, two fundamental aspects of the right of education can be mentioned. The first is to provide it with public resources and the provision of access to it by all social classes, and the second is that this education should be of quality and equal for all classes.

In this study, the aid policies followed in schools for poor students with low socioeconomic level were discussed. The research showed that systematic and common policies for poor students lacked at schools and education in Turkey is not provided at a similar quality or equally on the basis of right. This is because the school-based aids are not practices that would eliminate the disadvantage the poor students. The aids are mainly in the form of clothing (mostly school uniform and winter jacket), shoes, stationery, etc. However, the right of education is guaranteed in the national legislation and international conventions that Turkey has signed. In practice, however, it seems that the aids made in schools have remained well-meant efforts and inadequate. Qualified and equal education opportunities for the poor have not been provided. In their study focusing on primary state schools, Ünal and his colleagues (2010) found that 
there was a difference in terms of environment possibilities and academic achievement among schools and schools differed according to the socioeconomic levels of parents.

Indeed, another data showing the resolution in Turkey is the indicators of socioeconomic status of the parents whose children are going to qualified and unqualified schools. In Turkey, science high schools are accepted as the most qualified schools that accept students based on exams while vocational high schools are characterized as unqualified and accept students with the lowest exam scores. According to the analysis results based on 2012 OECD data conducted by Oral and Mcgivney (2014), when distribution of 15 years-old students to secondary schools based on socioeconomic levels was examined, it was observed that $51 \%$ of students at science high schools came from the highest socioeconomic level ( $5^{\text {th }} 20 \%$ zone). On the other hand, $23 \%$ of the students at vocational high schools came from the lowest socioeconomic level ( $1^{\text {st }} 20 \%$ zone). When this data is addressed in conjunction with the research findings, it shows that poor students that are coming from disadvantaged families are mostly involved in low-level schools in terms of performance and quality, but there are no policies to overcome the disadvantages of poor students there. However, participants often expressed that the current system was not fair, leaving schools alone with their own fate. This may mean that the cycle of inequality and poverty continue in society.

According to 2013 data, Turkey is the country with the highest income inequality after Mexico among OECD countries. According to the 2014 Global Wealth Report, the richest 10\% in Turkey has $77.7 \%$ of the country's prosperity (ERG, 2016). It has been supported in various studies that socioeconomic status is an important factor in access to educational opportunities in Turkey. These studies also reveal that poverty is a factor leading to multiple disadvantages in education (Aslan, 2017; Acemoğlu \& Pischke, 2000; ERG, 2016; Oral \& Mcgivney, 2014; Polat, 2007; Sirin, 2005; Gelbal, 2008). However, the education systems that have the highest performance are those that maintain high success for all socioeconomic income levels. Investing in students from low socioeconomic families returns to the society as sustainable growth. For this reason, an egalitarian and inclusive education system is one of the most effective ways to make society more productive (Oral \& Mcgivney, 2014).

On the other hand, it is seen that academic and social aids are almost never done in schools for poor students. Only one of the participants stated that academic help was given. However, research shows that the education level of parents of students with low socioeconomic level is also low (Aslan, 2014, 2017). This means that the child cannot get help for lessons at home. In fact, there are many studies showing that the academic success of the child is getting higher as the educational level of the parents increases (Aslan, 2017; Akyol, Sungur, \& Tekkaya, 2010; DeGarmo, Forgatch, \& Martinez, 1999; Hall, Davis, Bolen, \& Chia, 1999; Hortaçsu, 1994; Kuyper, Van der Werf, \& Lubbers, 2000; Öksüzler \& Sürekçi, 2010; Yılmaz, 2000). Explained using the concepts such as "cultural capital" by Bourdieu and "human capital" by Coleman, it is widely accepted that the educational level of parents is an important determiner of children's academic achievement. It can therefore be expected that this disadvantage for poor students can be compensated by different academic and social support programs at the school. In a study carried out by Diaz (1989 as cited in Sadi et al., 2014), it was found that the most important characteristic that differentiates the students with low academic achievement carrying the risk of failing from others was the lack of parent support and care. It can be said that the lack of parent support is higher in families with low socioeconomic status.

Another result of this study is that the majority of aid is done once or twice a year, although the frequency of aid varies according to schools. The reason for this is that there are no regular budgets that schools can use for help. Schools create the resources from a wide range of parts such as education staff, various public institutions, municipalities, charities, parents and children, and associations or non-governmental organizations. Since the socioeconomic levels of the parents are different from each other and the poor students often concentrate on the same schools, the amount of donation varies. Participants also mentioned that unethical situations were experienced during the collection and dissemination of aids to schools. In the process of collecting these aids, especially at the lower socioeconomic level, there are serious difficulties that cause both educators, parents and students to be in a difficult situation, and there are significant differences between the lower and upper socioeconomic schools in terms of the amount of donations and business revenues. The least donations are collected at the lower socioeconomic schools where the poorest students are located, and the most donations are collected at the upper socioeconomic schools where the richest students are located. For example, in a study conducted in 2011, two primary schools were compared in terms of cash aid they created. For the first school, 307 TL per student and $11 \mathrm{TL}$ for the second one were determined with the resources they created (ERG, 2016). Accordingly, in the first school, the aids given to a student is about 27 times more than a student in the second school. This deepens the inequality and divergence between schools in terms of quality and academic achievement.

On the other hand, due to the neo-liberal policies pursued in Turkey, educational burden on both wealthy and poor

| Kastamonu Eğitim Dergisi, 27(5), 2019 | 
families is increasing. Public resources are inadequate to meet the basic needs of schools. Among the school administrators who participated in the research, primary and secondary school administrators stated that the special incomes collected were spent on the compulsory school expenses of the school rather than to aid activities for the students with low socioeconomic level. For this reason, the school administrators try to collect the in-kind or financial aid from the parents during registration and during the academic year. These aids have become almost an obligation in practice under the name "donation". Therefore, the situation is heartbreaking for the poor who cannot afford this burden. A great body of research on schools' extra budgetary income resources or parents' (household) educational expenditures has been carried out in Turkey (Arslan, 2000; Akça, 2002; Devlet İstatistik Enstitüsü [DiE], 2003; Kavak, Ergin, \& Gökçe, 1997; Öztürk, 2002; Gümüş, Tümkaya, \& Dönmezer, 2004; Köse \& Şaşmaz, 2014; Yolcu, 2007). One of the most comprehensive of them is the "Turkey Educational Expenditures Research" conducted by DIE in 2002. According to this research, $64.5 \%$ of education expenditures are made by central government and $34.8 \%$ by private sources. $94.5 \%$ of private sources are household expenditures. Another research is the doctoral dissertation carried out by Yolcu in 2007. According to the findings of this research, it was determined that incomes were created from 60 different sources in primary education schools, involving especially compulsory donations from parents.

The findings of studies that examine schools' income sources according to the socioeconomic level (SEL) are striking in terms of revealing income inequality in schools. In a study conducted in the province of Ankara, it was found that when the income sources of the Parent-Teacher Associations are analyzed in terms of SEL variable, the donation income of the schools in the upper SEL is about four times higher than the donation income of the schools in the lower SEL (Özdemir, 2011). Within the scope of the current study, a considerable number of participants has pointed out that the special resources created in schools differed based on the socioeconomic environments of schools. Indeed, it is often emphasized that these differences deepen inequalities in schools.

It seems unlikely that schools will be able to effectively pursue the policies regarding students with low socioeconomic level. To solve the problem of financing, more systematic and broader model proposals are needed. Although the efforts made by schools are important, there is a need for regulatory and holistic politics at the macro level. Existing policies seem to deepen, rather than reduce or eliminate, the inequalities that exist between students or schools. As often expressed by the participants, while allocating the budget to schools, it is necessary to pursue various regulatory policies that eliminate injustices among schools, especially those involving the disadvantaged poor children with low socioeconomic status. The permanent solution is to achieve the social state that is emphasized in the Article 5 of the Constitution of the Republic of Turkey. It is important that poor students with low socioeconomic level are supported and monitored, not only economically, but also socially and academically.

In this study, it was determined what kind of aids were made in the schools, how often they were made, the source of the aids, and what could be done in this regard. This study is the first research on the aids made to poor students at schools in Turkey, but there are also some limitations of the research. For example, how many students have benefited from the aids was not able to be determined because they are not regularly recorded in schools. This research focuses on school policies, but research can also be planned on individual life stories of students / families receiving aids. It is also worth investigating the opinions of the families whose children receive the aids.

\section{References}

Acemoğlu, D., \& Pischke, J. S. (2000). Changes in The Wage Structure, Family Income, And Children's Education. Retrieved [02/07/2013] from http://econ.lse.ac.uk/staff/spischke/nels5.pdf.

Âdem, M. (1993). Ulusal Eğitim Politikamız ve Finansmanı. Ankara: Ankara Üniversitesi Eğitim Bilimleri Yayınları No:172.

Akça, Ş. (2002). Ailelerin ilköğretim kademesine yaptıkları eğitim harcamaları Ankara ili örneği. Yayımlanmamış Yüksek Lisans Tezi. Ankara Üniversitesi Eğitim Bilimleri Enstitüsü, Ankara.

Anıl, D., Özer Özkan, Y., \& Demir, E. (2012). PISA 2012 Araştırması Ulusal Nihai Rapor. Ankara: Işkur Matbaacılık.

Apple, M. W. (2004). Neoliberalizm ve Eğitim Politikaları Üzerine Eleştirel Yazılar. (çev. F. Gök vd.). Ankara: Eğitim Sen Yayınları.

Arslan, S. (2000). Ankara ilinde ortaöğretim okullarının özel gelir kaynakları. Yayınlanmamış Yüksek Lisans Tezi. Ankara Üniversitesi Sosyal Bilimler Enstitüsü, Ankara.

Aslan, G. (2015). An Analysis Regarding The Equality Perceptions Of Educational Administrators. The Anthropologist, 20 (1-2), 40-49.

Aslan, G. (2016). Taşımalı Eğitim Kapsamındaki Öğrencilerin Ortaöğretime Geçiş Başarılarının Eğitimsel Eşitlik Temelli Bir Analizi. In K. Beycioğlu, N. Özer, D. Koşar \& I. Şahin (Eds.), Eğitim Yönetimi Araştırmaları (pp. 1-17). Ankara: Pegem yayınevi.

Aslan, G. (2017).Determinants of Student Successes in Transition from Basic Education to Secondary Education (TEOG) Examination: An Analysis Related to Non-School Variables. Education and Science, 42 (190), 211-236.

| Kastamonu Eğitim Dergisi, 27(5), 2019| 
Balcı, A. (2004). Sosyal Bilimlerde Araştırma Yöntem, Teknik ve İlkeler. (4. bsı). Ankara: Pegem Yayıncılık.

Balcı, A. (2014). Etkili Okul ve Okul Geliştirme (7. bs.). Ankara: Pegem Akademi.

Boratav, K. (1997). Yapısal Uyum ve Bölüşüm: Uluslararası Bir Bilanço. Türk-ış 97 Yıllığı 1990'larin Bilançosu Değerlendirme Yazıları 2 (pp. 31-45). Ankara: Türk-Iş yayınları.

Bowles, S. (1977). Eşitsiz Eğitim ve Toplumsal İşbölümünün Yeniden Üretimi, (çev. K. İnal), Power and Ideology in Education. New York: Oxford University Press.

Coleman, J. S. (1988). Social Capital in The Creation of Human Capital. American Journal of Sociology, 94, 95-120.

DiE. ( 2003). Türkiye Eğitim Harcamaları Araşttrması 2002 Ankara: DiE matbaası, ISBN 975-19-3867-8

Dinçer, M. A., \& Kolaşin, G. U. (2009). Türkiye’de Öğrenci Başarısında Eşitsizliğin Belirleyicileri. İstanbul: Sabancı Üniversitesi Yayınları.

Ercan, F. (1997). Neo-Liberalizm ve Yapısal Uyum Politikalarının Eğitim Hakkı Üzerindeki Etkileri. Türk-Iş 97 Yıllığı 1990’larin Bilançosu Değerlendirme Yazıları 2 (pp. 46-73). Ankara: Türk-iş yayınları.

Ercan, F. (1998). Eğitim ve Kapitalizm: Neo-Liberal Eğitim Ekonomisinin Eleştirisi. İstanbul: Bilim Yayıncılık.

ERG. (2009). Eğitimde Eşitlik Politika Analizi ve Öneriler. İstanbul: Sabancı Üniversitesi Yayınları.

Gelbal, S. (2008). Sekizinci Sınıf Öğrencilerinin Sosyoekonomik Özelliklerinin Türkçe Başarısı Üzerine Etkisi. Eğitim ve Bilim, 33(150), 1-13.

Gök, F. (2004). Eğitimin Özelleştirilmesi. In N. Balkan, S. Savran (Haz.), Neoliberalizmin Tahribatı (pp. 94-110). Ankara: Metis yayınları. Gök, F. (2013). Türkiye'de Eleştirel Eğitimin Gündemi. In N. Kurul, T. Öztürk \& İ. Metinnam (Der), Kamusal Eğitim Eleştirel Yazılar. Ankara: Siyasal Kitapevi.

Gümüş, A., Tümkaya, S., \& Dönmez, T. (2004). Sıkıştırılmış Okullar (Adana'da İlköğretim Okulları, Öğretmenleri ve Öğrencileri Üzerine Yapılmış Bir Araştırma). Ankara: Eğitim Sen Yayınları.

Hoy, W. K., \& Miskel, C.G. (2016). Eğitim Yönetimi Teori Araştırma ve Uygulama (7.baskıdan çev.) (S.Turan, çev. ed.). Ankara: Nobel Yayınevi. Karakütük, K. (2012). Eğitim Planlaması. Birinci Baskı, Ankara: Elhan Yayınevi.

Kavak, Y., Ekinci, E., \& Gökçe, F. (1997). İlköğretimde Kaynak Arayışları. Ankara: Şafak Matbaacılık.

Kiraz, Z. (2014). Okullar Arasındaki Ayrışmanın Çözümlenmesi: Çankaya Örneği. The Journal of Academic Social Science, 2(7), 72-100.

Köse, A., \& Şaşmaz, A. (2014). ilköğretim Kurumlarının Mali Yönetimi Araştırma Raporu. Retrieved [12/07/2018] from http:// www.egitimreformugirisimi.org/wp-content/uploads/2017/03/ERG_MaliYonetimArastirmaRaporu.pdf.

Kurul, N. (2012). Eğitim Finansmanı. Genişletilmiş ve Gözden Geçirilmiş 2. Baskı, Ankara: Siyasal Kitapevi.

MEB. (2017a). Milli Eğitim İstatistikleri Örgün Eğitim 2016-2017. Ankara: MEB Strateji Geliştirme Başkanlığı yayınları.

MEB. (2017b). 340 Bin Öğrenciye Özel Okul Teşviki Verilecek. Retrieved [18.12.2017] from http://www.meb.gov.tr/340-bin-ogrenciye-ozel-okul-tesviki-verilecek/haber/14240/tr.

Miles, M. B., \& A. M. Huberman. (1994). An Expanded Sourcebook Qualitative Data Analysis. California: Sage Publications.

OECD. (2007). Education At a Glance. OECD Indicators 2007. Paris.

Önder, İ. (2002). Eğitim-Öğretim Konusu/Sorunu. Özgür Üniversite Formu, 17, 51-60.

Özdemir, N. (2011). İlköğretim finansmanında bir araç: Okul-aile birliği bütçe analizi Ankara ili örneği. Yayımlanmamış Yüksek Lisans Tezi. Hacettepe Üniversitesi Sosyal Bilimler Enstitüsü, Ankara.

Özsoy, S. (2002). Yükseköğretimde hakkaniyet ve eşitlik sorunsalı: Türkiye'deki finansal yapıyla ilgili bir çözümleme. Yayımlanmamış Doktora Tezi. Anakara Üniversitesi Sosyal Bilimler Enstitüsü, Ankara.

Öztürk, Ş. (2002). İlköğretim okullarının finansman kaynakları Ankara ili Polatlı ilçesi örneği. Yayımlanmamış Yüksek Lisans Tezi. Ankara Üniversitesi Eğitim Bilimleri Enstitüsü, Ankara.

Polat, S. (2007). Eğitim politikalarının sosyal adalet açısından sonuçları konusunda yönetici ve öğretmen görüşleri. Yayınlanmamış Doktora Tezi. Ankara Üniversitesi Eğitim Bilimleri Enstitüsü, Ankara.

Sadi, Ö., Uyar, M., \& Yalçın, H. (2014). Lise Öğrencilerinin Biyoloji Dersi Başarılarında, Cinsiyet, Sınıf Düzeyi ve Aile Yapısının Rolü. Eğitim ve Öğretim Araştırmaları Dergisi, 3(2), 138-151.

Sirin, S. R. (2005). Socioeconomic Status and Academic Achievement: A Meta-Analytic Review of Research. Review of Educational Research, 75, 417-453.

Stewart, F. (1995). Eğitim ve Uyum: 1980'lerin Deneyimi ve 1990'lar İçin Bazı Dersler. (çev. İ. Eser.) In Piyasa Güçleri ve Küresel Kalkınma (pp. 169-204). İstanbul: Yapı Kredi yayınları.

Tan, M. (1987). Eğitimsel Fırsat Eşitliği. Ankara Üniversitesi Eğitim Bilimleri Fakültesi Dergisi, 20(1-2), 245-259.

Torche, F. (2005). Privatization Reform and Inequality of Educational Opportunity: The Case of Chile. Sociology of Education,78, 316-343. DOI: 10.1177/003804070507800403

TÜiK. (2013). Hanehalkı Tüketim Harcaması. Haber Bülteni, Sayı: 13579, Retrieved [22/03/2014] from www.tüik.gov.tr.

UN. (2010). Millennium Development Goals Report Turkey 2010. Retrieved [26/05/2014] from http://planipolis.iiep.unesco.org/ upload/Turkey/Turkey_MDG_2010.pdf.

| Kastamonu Eğitim Dergisi, 27(5), 2019| 
Ünal, I., Özsoy, S., Yıldız, A., Güngör, S. Aylar, E., \& Çankaya, D. (2010). Eğitimde Toplumsal Ayrışma. Ankara: Ankara Üniversitesi Basımevi.

Ünal, L. I. (2002). Eğitimin Yapısal Uyumu. Özgür Üniversite Formu, 17, 127-128.

WB. (2013). Promoting Excellence in Turkey's Schools. Retrieved [26/05/2014] from http://www-wds.worldbank.org/external/default. Yıldırım, A., \& H. Şimşek. (2008). Sosyal Bilimlerde Nitel Araştırma Yöntemleri. Ankara: Seçkin Yayıncılık.

Yılmaz, G. (213). Dünden Bugüne 'Parasız Eğitim'. In N. Kurul, T. Öztürk, İ. Metinnam (Der.). Kamusal Eğitim Eleştirel Yazılar (pp. 47-56). Ankara: Siyasal yayınevi.

Yolcu, H. (2007). Türkiye'de ilköğretim finansmanının değerlendirilmesi. Yayınlanmamış Doktora Tezi. Ankara Üniversitesi Eğitim Bilimleri Enstitüsü, Ankara.

YÖK. (2017). Yükseköğretim İstatistikleri. Ankara: YÖK yayınları.

\section{Appendix-1. Demographics}

\begin{tabular}{|c|c|c|c|c|c|}
\hline Participant Codes & Gender & Title & Professional Seniority & Education Level & The SEL of the School \\
\hline P1 & Male & Assistant principals & 10 & Middle & Medium \\
\hline P2 & Male & School principals & 16 & Primary & Lower \\
\hline P3 & Male & School principals & 18 & Primary & Medium \\
\hline P4 & Male & School principals & 18 & Secondary & Higher \\
\hline P5 & Female & School principals & 16 & Primary & Lower \\
\hline P6 & Male & Assistant principals & 14 & Middle & Medium \\
\hline P7 & Male & School principals & 15 & Preschool & Medium \\
\hline P8 & Male & Teacher & 5 & Middle & Lower \\
\hline P9 & Male & Assistant principals & 12 & Middle & Medium \\
\hline P10 & Male & Teacher & 22 & Primary & Medium \\
\hline P11 & Male & School principals & 12 & Primary & Lower \\
\hline P12 & Male & School principals & 23 & Secondary & Higher \\
\hline P13 & Female & Teacher & 4 & Primary & Lower \\
\hline P14 & Male & Assistant principals & 14 & Secondary & Lower \\
\hline P15 & Male & School principals & 14 & Primary & Lower \\
\hline P16 & Male & Teacher & 10 & Primary & Lower \\
\hline P17 & Female & Teacher & 2 & Primary & Lower \\
\hline P18 & Male & School principals & 18 & Primary & Higher \\
\hline P19 & Male & School principals & 13 & Middle & Medium \\
\hline P20 & Male & Teacher & 6 & Secondary & Higher \\
\hline P21 & Male & Teacher & 13 & Primary & Lower \\
\hline P22 & Female & Teacher & 3 & Primary & Medium \\
\hline P23 & Male & Teacher & 7 & Primary & Medium \\
\hline P24 & Male & School principals & 16 & Secondary & Medium \\
\hline P25 & Male & School principals & 13 & Secondary & Lower \\
\hline P26 & Male & School principals & 12 & Middle & Higher \\
\hline P27 & Male & Teacher & 1 & Middle & Medium \\
\hline P28 & Male & School principals & 12 & Primary & Medium \\
\hline P29 & Male & School principals & 18 & Middle & Medium \\
\hline P30 & Male & Teacher & 16 & Secondary & Medium \\
\hline P31 & Male & Teacher & 20 & Primary & Lower \\
\hline P32 & Male & School principals & 13 & Middle & Lower \\
\hline P33 & Male & School principals & 22 & Secondary & Lower \\
\hline P34 & Male & Assistant principals & 20 & Secondary & Lower \\
\hline P35 & Male & Assistant principals & 16 & Secondary & Lower \\
\hline P36 & Male & Teacher & 16 & Primary & Higher \\
\hline P37 & Male & School principals & 16 & Secondary & Lower \\
\hline P38 & Male & Assistant principals & 16 & Middle & Medium \\
\hline P39 & Male & School principals & 21 & Middle & Lower \\
\hline P40 & Male & Assistant principals & 13 & Secondary & Lower \\
\hline P41 & Female & School principals & 16 & Preschool & Medium \\
\hline
\end{tabular}




\begin{tabular}{|c|c|c|c|c|c|}
\hline Participant Codes & Gender & Title & Professional Seniority & Education Level & The SEL of the School \\
\hline P42 & Male & Teacher & 5 & Primary & Lower \\
\hline P43 & Female & School principals & 24 & Preschool & Lower \\
\hline P44 & Male & School principals & 17 & Secondary & Lower \\
\hline P45 & Male & School principals & 13 & Middle & Lower \\
\hline P46 & Male & Assistant principals & 6 & Primary & Lower \\
\hline P47 & Male & Assistant principals & 8 & Secondary & Lower \\
\hline P48 & Male & Assistant principals & 12 & Preschool & Lower \\
\hline P59 & Female & School principals & 12 & Preschool & Medium \\
\hline P50 & Male & School principals & 17 & Primary & Medium \\
\hline P51 & Male & Teacher & 22 & Secondary & Higher \\
\hline P52 & Female & Assistant principals & 14 & Preschool & Higher \\
\hline P53 & Male & Assistant principals & 17 & Secondary & Medium \\
\hline P54 & Male & Assistant principals & 16 & Secondary & Lower \\
\hline P55 & Female & Teacher & 10 & Middle & Lower \\
\hline P56 & Male & School principals & 12 & Primary & Lower \\
\hline P57 & Male & Assistant principals & 12 & Middle & Lower \\
\hline P58 & Female & Assistant principals & 7 & Secondary & Higher \\
\hline P59 & Male & School principals & 16 & Secondary & Lower \\
\hline P60 & Female & Assistant principals & 7 & Primary & Medium \\
\hline P61 & Female & Assistant principals & 16 & Secondary & Medium \\
\hline P62 & Male & School principals & 22 & Middle & Medium \\
\hline P63 & Male & Teacher & 5 & Secondary & Higher \\
\hline P64 & Female & School principals & 12 & Preschool & Higher \\
\hline P65 & Female & School principals & 18 & Preschool & Medium \\
\hline P66 & Male & School principals & 22 & Secondary & Higher \\
\hline P67 & Male & Teacher & 4 & Middle & Lower \\
\hline P68 & Female & School principals & 24 & Primary & Lower \\
\hline P69 & Male & Assistant principals & 13 & Middle & Lower \\
\hline P70 & Female & Assistant principals & 14 & Preschool & Lower \\
\hline P71 & Male & School principals & 17 & Middle & Medium \\
\hline P72 & Male & Teacher & 4 & Secondary & Medium \\
\hline P73 & Male & School principals & 10 & Secondary & Medium \\
\hline P74 & Male & School principals & 8 & Middle & Medium \\
\hline
\end{tabular}

